\title{
Microbiological quality, proximate composition and in vitro starch/protein digestibility of Sorghum bicolor flour fermented with lactic acid bacteria consortia
}

\author{
Alloysius Chibuike Ogodo ${ }^{*}$, Ositadinma Chinyere Ugbogu², Reginald Azu Onyeagba ${ }^{2}$ \\ and Hope Chukwuemeka Okereke ${ }^{2}$
}

\begin{abstract}
Background: This study evaluated the effect of lactic acid bacteria (LAB) consortium fermentation on proximate and in vitro starch and protein digestibility of sorghum flour using standard techniques at 12-h intervals. Lactic acid bacteria previously isolated from fermenting maize and sorghum were combined as follows: Lactobacillus nantensis LP33 + Lactobacillus plantarum WCFS1 + Lactobacillus fermentum CIP102980 + Lactobacillus rhamnosus GG ATCC53/03 + Lactobacillus reuteri DSM20016 and Lactobacillus fermentum CIP102980 + Lactobacillus brevis ATCC14869 + Lactobacillus nantensis LP33 + Pediococcus acidilactici DSM20284 + Lactobacillus plantarum WCFS1 for consortium from maize and sorghum, respectively, and used to ferment sorghum flour. The flour was also fermented spontaneously for comparison.
\end{abstract}

Results: The result showed significant $(p<0.05)$ increase in moisture, ash and protein contents; while fiber, lipid and carbohydrate contents decreased with increasing fermentation time in all set-ups. The in vitro protein digestibility increased significantly $(p<0.05)$ from $63.68 \pm 1.46$ to $79.89 \pm 1.14 \%, 63.68 \pm 1.46$ to $83.72 \pm 2.08 \%$ and $63.68 \pm 1.46$ to $84.28 \pm 2.16 \%$ for naturally, LAB consortium from maize-fermented and LAB consortium from sorghum-fermented samples, respectively. Total viable count and total lactic acid bacteria count increased with fermentation with no coliform and fungal count in the consortia-fermented sample. The occurrence of isolates showed that only starter organisms were isolated from the consortia fermentations.

Conclusion: This study has shown the effectiveness of $L A B$ consortium fermentation in improving the nutritional quality and in vitro starch/protein digestibility of sorghum flour which holds potential in food fortification by food industries.

Keywords: LAB consortium, Proximate analysis, Fermentation, IVPD, IVSD, Cereals

\footnotetext{
*Correspondence: ogodoac@fuwukari.edu.ng;

alloysiuschibuike@yahoo.com

${ }^{1}$ Department of Microbiology, Faculty of Pure and Applied Sciences,

Federal University Wukari, P.M.B. 1020, Wukari, Taraba State, Nigeria

Full list of author information is available at the end of the article
} 


\section{Background}

Sorghum (Sorghum bicolor (L.) Moench) is ranked fifth among world food grain [1]. The annual world production is over 60 million tons, of which Africa produces about 20 million tons [2]. About 45 million hectares of sorghum are cultivated in the world and USA is the number one producer followed by Nigeria, India, Mexico, China, Argentina, Sudan, Ethiopia, Somalia, Australia, Burkina Faso, Brazil [3]. Sorghum is a good source of energy, proteins, carbohydrates, vitamins and minerals including the trace elements, particularly iron and zinc, except calcium. Sorghum grain contains minerals such as phosphorus, potassium and magnesium in varying quantities $[4,5]$. Sorghum and millet contain high amount of starch and its digestibility is greatly influenced by plant type and depends on physicochemical characteristics of the starch and other factors like plant microstructure, composition, processing and storage conditions. Moreover, traditional treatments such as soaking, cooking, germinating and fermenting have been used to improve nutritional quality of the sorghum [5].

Fermentation increases the starch and protein digestibility as well as nutritive value [6]. Fermentation also leads to an increase in protein content, enhancement of carbohydrate accessibility, improvement in amino acid balance, decrease in anti-nutritional factors like tannin and phytic acid [6]. LAB fermentation is a common way of preparing food traditionally in Africa. Some of the traditionally fermented foods in Africa include maize porridge, alcoholic beverages and dairy products. Some of the main reasons for the fermentation practice using $\mathrm{LAB}$ are to increase food palatability and improve the quality of food by increasing the availability of proteins and vitamins [7]. Furthermore, LAB confers preservative and detoxifying effects on food as well. When used regularly, LAB-fermented foods boost the immune system and strengthen the body in the fight against pathogenic bacterial infections. Thus, LAB fermentation is not only of a major economic importance, but also promotes human health in Africa. Hence, the aim of this study is to evaluate the microbiological quality, proximate composition and the in vitro starch/protein digestibility of sorghum flour fermented with lactic acid bacteria consortia.

\section{Methods}

\section{Collection of sample}

Red variety of sorghum (Sorghum bicolor) were bought from Mushin market of Lagos, Lagos State, Nigeria and transported to the laboratory in a clean polythene bags for analysis at Federal Institute of Industrial Research Oshodi (FIIRO). Lactic acid bacteria used as starter culture were previously isolated from fermenting maize and sorghum.

\section{Choice of starter culture (inoculum)}

The lactic acid bacteria consortium from maize and from sorghum was selected based on their tolerance to acid, salt, lowering of $\mathrm{pH}$, level of acid production and growth on nutrient-depleted medium after pre-fermentation studies, as well as their benefits in food fermentation reported by other researchers [8-10].

\section{Sample preparation}

The raw grains of sorghum were freed of foreign materials, washed with clean tap water and rinsed with distilled water. The samples were dried with hot air oven $(\mathrm{GL}$, England) at $60{ }^{\circ} \mathrm{C}$ for $8 \mathrm{~h}$. The dried samples were milled into powder using milling machine disinfected with $70 \%$ ethanol and stored in clean air tight containers at $4{ }^{\circ} \mathrm{C}$ for further use.

\section{Inoculum/starter culture preparation}

The inoculum (starter culture) was prepared according to the method described by Ogodo et al. [11]. Five lactic acid bacteria were combined according to their sources as follows; Lactobacillus plantarum WCFS1+Lactobacillus rhamnosus GG ATCC 53/03+Lactobacillus nantensis LP33+Lactobacillus fermentum CIP 102980 + Lactobacillus reuteri DSM 20016 (consortium from maize); Pediococcus acidilactici DSM 20284 + Lactobacillus fermentum CIP 102980+Lactobacillus brevis ATCC 14869+Lactobacillus nantensis LP33 + Lactobacillus plantarum WCFS1 (consortium from sorghum). These were grown as co-culture in Erlenmeyer flasks containing MRS broth, respectively, and incubated for $48 \mathrm{~h}$ in an orbital shaker incubator (REMI/396LAG) at $37{ }^{\circ} \mathrm{C}$ for the inoculum to build-up. The inocula were harvested by centrifugation at $5000 \mathrm{~g}$ for $10 \mathrm{~min}$ and washed with distilled water. The washed cells were diluted using sterile distilled water to obtain 0.5 McFarland standards.

\section{Fermentation of sorghum flour}

Fermentation of the sorghum flour was carried out following a slight modification of the method of Ogodo et al. [12]. Exactly, $500 \mathrm{~g}$ of the flour was mixed with $1000 \mathrm{~mL}$ of distilled water followed by addition of $0.5 \mathrm{~g} / \mathrm{L}$ of potassium sorbate to inhibit fungi and other contaminating microorganisms (verified by no observable growth on plate count agar after 18-24 h of incubation). The mixture was inoculated with $10 \mathrm{~mL}$ of $10^{8}$ cells $/ \mathrm{mL}$ of the mixture of the lactic acid bacteria suspension and allowed to ferment. The starter organisms and potassium sorbate were not added to control trial for spontaneous fermentation. Samples were withdrawn at $12-\mathrm{h}$ intervals, wrapped in aluminum foil and dried at $60{ }^{\circ} \mathrm{C}$ for $8 \mathrm{~h}$ and analyzed for proximate composition and in vitro starch/ protein digestibility at periods of $0,12,24,36$ and $48 \mathrm{~h}$. 


\section{Proximate analysis}

Moisture, ash, protein, lipids, fiber and carbohydrate contents were determined according to AOAC [13] methods.

\section{In vitro starch and protein digestibility (IVSD)}

In vitro starch digestibility (IVSD) was determined according to the method described by Singh et al. [6]. The in vitro protein digestibility of the samples was determined by enzymatic method of Monjula and John [14].

\section{Enumeration, isolation and identification of microorganisms}

The method of Ogodo et al. [15] was used for the enumeration and isolation of microorganisms with slight modification. A tenfold serial dilution of homogenized $1.0 \mathrm{~g}$ of sample in $9.0 \mathrm{~mL}$ of peptone water was prepared and $0.1 \mathrm{~mL}$ from $10^{-5}$ dilution factor was transferred to plate count agar (PCA) (Oxoid), MacConkey agar (MA) (Oxoid), deMan Rogosa and Sharpe agar (MRS) (Oxoid) and Sabouraud Dextrose agar (SDA) (Oxoid) for enumeration of total viable count (TVB), total coliform count (TCC), total lactic acid bacteria count (TLBC) and total fungal counts (TFC), respectively. The cultured plates were incubated at room temperature for $24 \mathrm{~h}$ and then counted. Pure cultures were obtained by successive streaking on fresh nutrient medium and subsequently identified [16-19]. The fungi were identified based on their physiological, morphological and biochemical characteristics and with reference to the methods described by [20-22].

\section{Statistical analysis}

The analyses were conducted in triplicate and the mean data \pm SD (standard deviation) were reported. Analysis of variance (ANOVA) for repeated measurements was used to analyze the data. The parameters analyzed were compared between natural fermentation, LAB consortium from maize fermentation and $\mathrm{LAB}$ consortium from sorghum fermentation using statistical package for the social sciences (SPSS) version 20.0 software. Significance was accepted at $p \leq 0.05$.

\section{Results}

Table 1 presents the effect of LAB consortium fermentation on the proximate composition of the sorghum flour. Moisture, ash and protein contents increased with increasing fermentation time and ranged from $9.84 \pm 0.04$ to $11.18 \pm 0.04 \%, 1.42 \pm 0.04$ to $2.21 \pm 0.03 \%$ and $10.39 \pm 0.27$ to $13.97 \pm 0.87 \%$, respectively. The highest increases were observed at LAB consortium from maize-fermented and $\mathrm{LAB}$ consortium from sorghum-fermented samples. The lipid, fiber and carbohydrate contents decreased with fermentation ranging from $3.42 \pm 0.03$ to $3.08 \pm 0.02 \%, 1.96 \pm 0.05$ to $0.54 \pm 0.04 \%$ and $72.97 \pm 0.12$ to $69.14 \pm 0.96 \%$, respectively.

Figure 1 presented the effect of fermentation on the percentage in vitro starch digestibility of the sorghum flour. The result showed a significant increase in the in vitro starch digestibility as fermentation time increases and increased from $10.68 \pm 0.92$ to $49.32 \pm 0.58 \%$ (naturally fermented), $10.68 \pm 0.92$ to $58.00 \pm 0.97 \%$ (LAB consortium from maize-fermented) and $10.68 \pm 0.92$ to $61.04 \pm 1.23$ (LAB consortium from sorghum-fermented) samples. The changes in the in vitro starch digestibility differed significantly $(p<0.05)$ at all-time intervals. However, the changes in the in vitro starch digestibility of LAB consortium from maize-fermented and $\mathrm{LAB}$ consortium from sorghumfermented samples did not differ significantly $(p>0.05)$.

Figure 2 presented the effect of fermentation on the percentage in vitro protein digestibility of the sorghum flour which showed a significant increase $(p<0.05)$ as fermentation time increases and ranged from $63.68 \pm 1.46$ to $79.89 \pm 1.14 \%$ (naturally fermented), $63.68 \pm 1.46$ to $83.72 \pm 2.08 \%$ (LAB consortium from maize-fermented) and $63.68 \pm 1.46$ to $84.28 \pm 2.16$ (LAB consortium from sorghum-fermented) samples.

Table 2 presented the effect of fermentation on the microbial load of sorghum sample under study. The total viable count (TVC) increased with increasing fermentation and ranged from $5.0 \times 10^{8} \mathrm{CFU} / \mathrm{g}$ to $1.64 \times 10^{9} \mathrm{CFU} / \mathrm{g}$. The total lactic acid bacteria count (TLBC) increased consistently to $36 \mathrm{~h}$ of fermentation and showed a slight decrease at $48 \mathrm{~h}$ of fermentation in all the fermentation set-ups and ranged from $4.92 \times 10^{8}$ to $9.0 \times 10^{8} \mathrm{CFU} / \mathrm{g}$. Coliform count (TCC) was only observed at $0 \mathrm{~h}$ of the naturally fermented sample $\left(8.0 \times 10^{2} \mathrm{CFU} / \mathrm{g}\right)$ while total fungal count ranged from $0.3 \times 10^{1}$ to $2.81 \times 10^{9} \mathrm{CFU} / \mathrm{g}$.

The occurrence of various bacteria and fungi in the fermented product is presented in Table 3. The predominant organisms isolated belong to lactic acid bacteria (LAB) group including L. fermentum, L. plantarum, Lactobacillus natensis, L. reuteri, L. rhamnosus, L. brevis, Lactococcus lactis, Lactobacillus bulgaricus, P. acidilactici and Leuconostoc species.

\section{Discussion}

In the present study, the moisture content showed an increase as the fermentation time increases and ranged from $9.84 \pm 0.04 \%(0 \mathrm{~h})$ to $11.18 \pm 0.04 \%$ (fermented with $\mathrm{LAB}$ consortium from maize). The values obtained in the present study were higher than $7.52 \%$ obtained 
Table 1 Proximate composition (\%) of LAB consortium fermented sorghum flour

\begin{tabular}{|c|c|c|c|c|c|c|c|c|c|}
\hline \multirow[t]{2}{*}{ FT (h) } & \multicolumn{3}{|l|}{ Moisture } & \multicolumn{3}{|l|}{ Ash } & \multicolumn{3}{|l|}{ Fat } \\
\hline & NF & MF & SF & NF & MF & SF & NF & MF & SF \\
\hline 0 & $9.84 \pm 0.04^{a}$ & $9.84 \pm 0.04^{a}$ & $9.84 \pm 0.04^{a}$ & $10.32 \pm 0.05^{b}$ & $10.32 \pm 0.05^{b}$ & $10.32 \pm 0.05^{b}$ & $3.42 \pm 0.04^{b}$ & $3.42 \pm 0.04^{b, g}$ & $3.42 \pm 0.04^{b}$ \\
\hline 12 & $10.11 \pm 0.08^{b}$ & $10.32 \pm 0.01^{c}$ & $10.28 \pm 0.06^{c, e}$ & $10.46 \pm 0.02^{c}$ & $10.51 \pm 0.06^{d}$ & $10.40 \pm 0.04^{c, k}$ & $3.34 \pm 0.04^{b, c}$ & $3.30 \pm 0.02^{g, h}$ & $3.32 \pm 0.10^{b, h, l}$ \\
\hline 24 & $10.68 \pm 0.15^{c}$ & $10.94 \pm 0.04^{d}$ & $10.88 \pm 0.04^{d, f}$ & $10.74 \pm 0.02^{e}$ & $10.88 \pm 0.05^{h}$ & $10.68 \pm 0.04^{e, l}$ & $3.30 \pm 0.04^{c, d}$ & $3.26 \pm 0.12^{h, i}$ & $3.28 \pm 0.02^{1, c, i}$ \\
\hline 36 & $10.87 \pm 0.05^{c, d}$ & $10.98 \pm 0.10^{\mathrm{d}, \mathrm{g}}$ & $10.96 \pm 0.03^{f, g}$ & $10.82 \pm 0.03^{f}$ & $10.90 \pm 0.04^{i}$ & $10.92 \pm 0.04^{\mathrm{f}, \mathrm{m}}$ & $3.24 \pm 0.12^{\mathrm{ce} e}$ & $3.12 \pm 0.04^{h, j}$ & $3.18 \pm 0.08^{\mathrm{e}, \mathrm{j}, \mathrm{m}}$ \\
\hline 48 & $10.98 \pm 0.02^{e}$ & $11.18 \pm 0.04^{h}$ & $11.04 \pm 0.05^{h, i}$ & $10.90 \pm 0.02^{9}$ & $10.96 \pm 0.04^{j}$ & $10.98 \pm 0.04^{g, n}$ & $3.14 \pm 0.01^{e, f}$ & $3.08 \pm 0.02^{\mathrm{j}, \mathrm{k}}$ & $3.10 \pm 0.10^{\mathrm{m}, \mathrm{e}, \mathrm{k}}$ \\
\hline \multirow[t]{2}{*}{ FT (h) } & \multicolumn{3}{|l|}{ Protein } & \multicolumn{3}{|l|}{ Fiber } & \multirow[t]{2}{*}{ Carbohydrate } & & \\
\hline & NF & MF & SF & NF & MF & SF & & & \\
\hline 0 & $10.39 \pm 0.26^{b}$ & $10.39 \pm 0.26^{b, g}$ & $10.39 \pm 0.26^{b}$ & $1.96 \pm 0.05^{b}$ & $1.96 \pm 0.05^{b}$ & $1.96 \pm 0.05^{b}$ & $72.97 \pm 0.12^{b}$ & $72.97 \pm 0.12^{b}$ & $72.97 \pm 0.12^{b}$ \\
\hline 12 & $11.07 \pm 0.92^{b, c}$ & $11.08 \pm 0.88^{g, c, h}$ & $11.12 \pm 0.09^{b, c, l}$ & $1.64 \pm 0.04^{c}$ & $1.58 \pm 0.07^{9}$ & $1.32 \pm 0.05^{k}$ & $72.33 \pm 0.66^{c}$ & $72.08 \pm 0.09^{c, g}$ & $72.23 \pm 0.11^{c, k}$ \\
\hline 24 & $11.74 \pm 0.64^{\mathrm{cdd}}$ & $11.63 \pm 0.09^{h, d, i}$ & $11.98 \pm 0.13^{1, \mathrm{~d}, \mathrm{~m}}$ & $1.28 \pm 0.03^{d}$ & $0.98 \pm 0.11^{h}$ & $0.84 \pm 0.07^{\mid}$ & $71.28 \pm 0.16^{\mathrm{cdd}}$ & $71.33 \pm 0.04^{g, d, h}$ & $71.10 \pm 0.99^{k, d, l}$ \\
\hline 36 & $12.53 \pm 0.03^{\mathrm{d}, \mathrm{e}}$ & $13.17 \pm 0.83^{i, e j}$ & $13.22 \pm 0.78^{m, e, n}$ & $0.92 \pm 0.10^{e}$ & $0.66 \pm 0.10^{i}$ & $0.65 \pm 0.05^{\mathrm{m}}$ & $70.55 \pm 0.68^{\mathrm{e}}$ & $70.07 \pm 0.11^{e, i}$ & $69.98 \pm 0.18^{\mathrm{e}, \mathrm{m}}$ \\
\hline 48 & $13.28 \pm 0.26^{e, f}$ & $13.69 \pm 0.09^{\mathrm{j}, \mathrm{fk}}$ & $13.97 \pm 0.87^{n, f, o}$ & $0.74 \pm 0.09^{e, f}$ & $0.59 \pm 0.03^{j}$ & $0.54 \pm 0.04^{n}$ & $69.94 \pm 0.10^{e, f}$ & $69.36 \pm 0.96^{\mathrm{i}, \mathrm{f}_{\mathrm{j}}}$ & $69.14 \pm 0.96^{\mathrm{m}, \mathrm{fn}}$ \\
\hline
\end{tabular}

FT: fermentation time in hours; NF: naturally fermented; MF: LAB consortium from maize fermented; SF: LAB consortium from sorghum fermented

All values are mean of triplicate determination and expressed as mean $\pm S D$

Values with different superscript on a row of a particular parameter are significantly different $(p<0.05)$

Values with different superscript on a column of a particular parameter are significantly different $(p<0.05)$

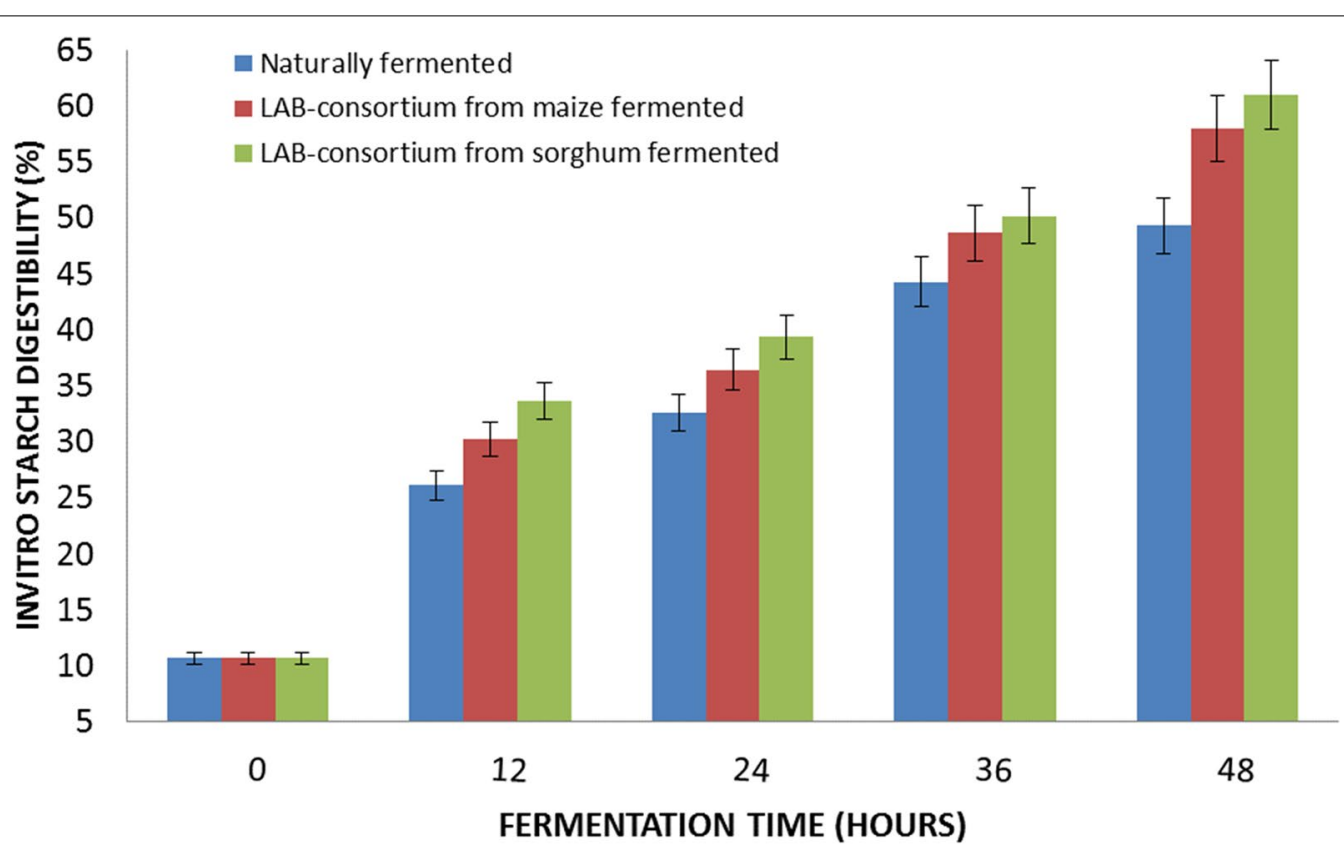

Fig. 1 Effect of $L A B$ consortium fermentation on in vitro starch digestibility of sorghum flours under study at different time intervals. Each point represents the mean of three independent experiments and error bars indicate \pm SE. There are significant differences ( $p<0.05)$ at each successive time interval when spontaneous fermentation is compared to LAB consortium from maize and LAB consortium from sorghum fermentations, respectively

by Ogunsakin et al. 23] but consistent with the report of Ojokoh and Bello [24]. However, the result fell within the range reported for millet [25]. The increase can be attributed to the addition of water to the substrate prior to fermentation. Moisture is an important parameter in the quality and acceptability of flour and flour products, as it affects the shelf life and microbial growth during storage [26]. The low moisture content obtained in this study 


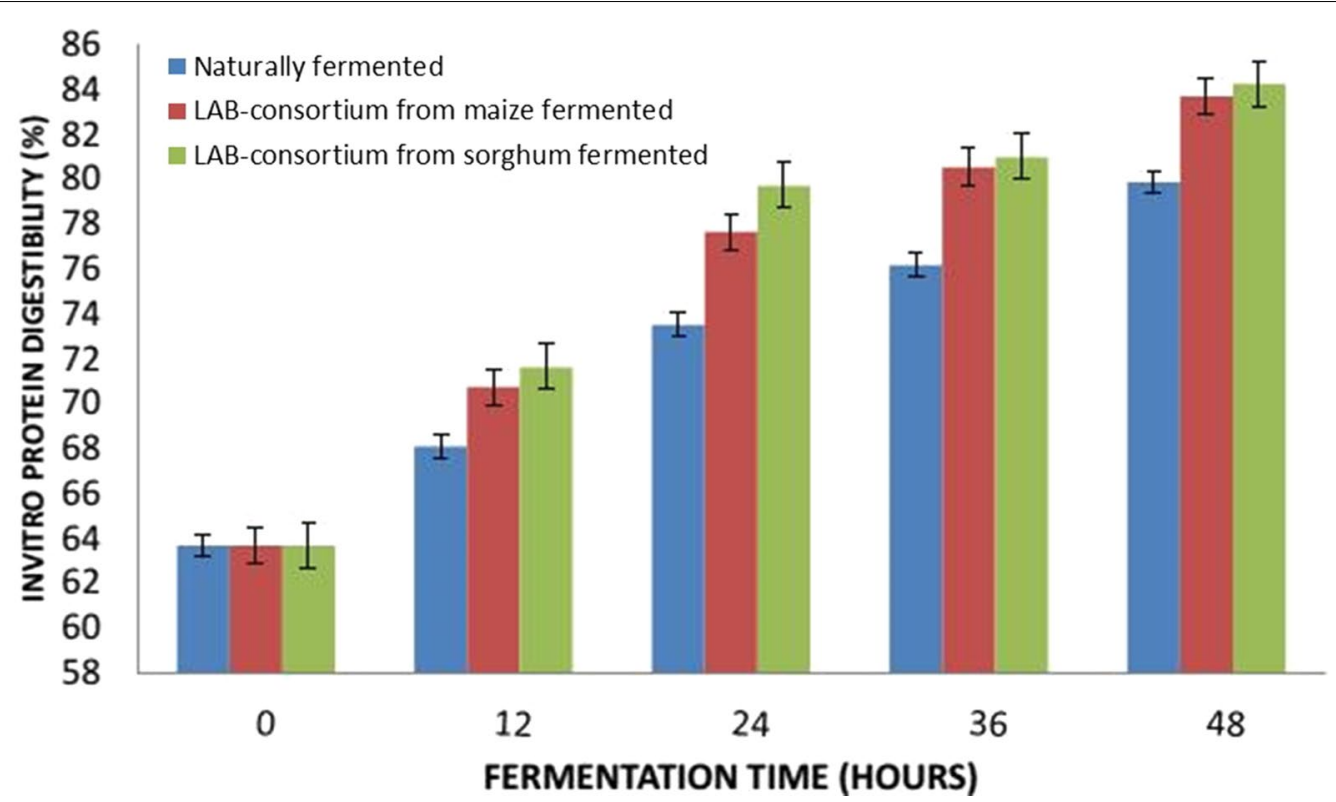

Fig. 2 Effect of $L A B$ consortium fermentation on in vitro protein digestibility of sorghum flours under study at different time intervals. Each point represents the mean of three independent experiments and error bars indicate \pm SE. There are significant differences $(p<0.05)$ at each successive time interval when spontaneous fermentation is compared to $L A B$ consortium from maize and $L A B$ consortium from sorghum fermentations, respectively

Table 2 Effect of fermentation on the microbial load (CFU/g) of the sorghum flour after natural (N), LAB consortium from maize $(M)$ and $L A B$ consortium from sorghum $(S)$ fermentation on different media

\begin{tabular}{|c|c|c|c|c|c|c|c|c|c|c|c|c|}
\hline \multirow[t]{2}{*}{ Time (h) } & \multicolumn{3}{|l|}{ PCA (TVC) } & \multicolumn{3}{|c|}{ MRS (TLBC) } & \multicolumn{3}{|l|}{ MCA (TCC) } & \multicolumn{3}{|l|}{ SDA (TFC) } \\
\hline & $\mathrm{N}$ & $M$ & $S$ & $\mathbf{N}$ & $M$ & $S$ & $\mathbf{N}$ & $M$ & $S$ & $\mathbf{N}$ & $M$ & $S$ \\
\hline 0 & $1.11 \times 10^{9}$ & $5.22 \times 10^{8}$ & $5.00 \times 10^{8}$ & $5.10 \times 10^{6}$ & $5.22 \times 10^{8}$ & $4.92 \times 10^{8}$ & $8.00 \times 10^{2}$ & $<10$ & $<10$ & $2.40 \times 10^{3}$ & $<10$ & $<10$ \\
\hline 12 & $1.55 \times 10^{9}$ & $7.10 \times 10^{8}$ & $7.62 \times 10^{8}$ & $5.47 \times 10^{6}$ & $6.89 \times 10^{8}$ & $7.01 \times 10^{8}$ & $<10$ & $<10$ & $<10$ & $2.81 \times 10^{3}$ & $<10$ & $<10$ \\
\hline 24 & $1.64 \times 10^{9}$ & $9.72 \times 10^{8}$ & $8.81 \times 10^{8}$ & $5.84 \times 10^{6}$ & $8.94 \times 10^{8}$ & $8.99 \times 10^{8}$ & $<10$ & $<10$ & $<10$ & $3.20 \times 10^{3}$ & $<10$ & $<10$ \\
\hline 36 & $1.49 \times 10^{9}$ & $8.61 \times 10^{8}$ & $8.40 \times 10^{8}$ & $5.53 \times 10^{6}$ & $8.96 \times 10^{8}$ & $9.00 \times 10^{8}$ & $<10$ & $<10$ & $<10$ & $3.52 \times 10^{3}$ & $<10$ & $<10$ \\
\hline 48 & $1.04 \times 10^{9}$ & $7.80 \times 10^{8}$ & $7.60 \times 10^{8}$ & $5.55 \times 10^{6}$ & $7.88 \times 10^{8}$ & $7.96 \times 10^{8}$ & $<10$ & $<10$ & $<10$ & $3.72 \times 10^{3}$ & $<10$ & $<10$ \\
\hline
\end{tabular}

Plate count agar (PCA) was used for total viable count (TVC), de Man Rogosa and Sharpe agar (MRS) used for lactic acid bacteria count (TLBC), MacConkey agar (MCA) used for total coliform count (TCC) while Sabouraud Dextrose agar (SDA) was used for total fungal count

There was no significant difference $(p>0.05)$ on the microbial load for each media

is desirable because it will enhance the storability of the flours [27].

The ash content increased from $1.42 \pm 0.04 \%$ in the unfermented sample to $2.21 \pm 0.03 \%$ in the $48 \mathrm{~h}$ fermented with $\mathrm{LAB}$ consortium from sorghum. The value at all the time intervals shows that the variations differ significantly $(p<0.05)$. There was significant difference $(p<0.05)$ between naturally fermented samples and the samples fermented with $\mathrm{LAB}$ consortium from maize and LAB consortium from sorghum. However, the variations did not show any significant difference between LAB consortium from maize- and sorghum-fermented samples. Yusufu et al. [28] reported $1.50 \pm 1.00 \%$ ash in weaning food prepared from sorghum which is slightly lower than the final fermentation product of the present study and also agreed with the report of Yagoub et al. [29]. Ash content increment is an indication of the level of mineral composition of the substrates [30]. The ash increment in this study was highest in sample fermented with $\mathrm{LAB}$ consortium from sorghum, followed by sample fermented with $\mathrm{LAB}$ consortium from maize and then the naturally fermented sample. This finding suggests the effectiveness of the consortia in improving the mineral composition of the substrates. 
Table 3 Occurrence of bacteria and fungi isolates in the fermented flour after natural (N), LAB consortium from maize (M) and LAB consortium from sorghum (S) fermentation

\begin{tabular}{lllll}
\hline S/N & Organisms isolated & \multicolumn{3}{l}{ Sorghum } \\
\cline { 3 - 5 } & & N & M & S \\
\hline 1. & Lactobacillus fermentum & + & + & + \\
2. & Lactobacillus plantarum & + & + & + \\
3. & Lactobacillus nantensis & - & + & + \\
4. & Lactobacillus reuteri & + & + & - \\
5. & Lactobacillus rhamnosus & - & + & - \\
6. & Lactobacillus brevis & - & - & + \\
7. & Lactococcus lactis & - & - & - \\
8. & Lactobacillus bulgaricus & + & - & - \\
9. & Pediococcus acidilactici & - & - & + \\
10. & Leuconostoc species & + & - & - \\
13. & Saccharomyces cerevisiae & + & - & - \\
\hline
\end{tabular}

+ : present, - : absent

In the present study, the fat content is $3.42 \pm 0.03 \%$ $(0 \mathrm{~h})$ to $3.08 \pm 0.02 \%$ (48-h LAB consortium from maize-fermented sample). Comparing values between the fermentation set-ups shows that LAB consortium from maize-fermented sample is significantly different $(p<0.05)$ when compared with the naturally fermented but did not differ with the LAB consortium from sorghum-fermented sample, while the LAB consortium from sorghum-fermented sample did not differ $(p>0.05)$ with the naturally fermented sample. The present finding was within the range 3.58-3.91\% reported by Afify et al. [5]. Also, El-Maki et al. [31] reported decrease in fat content during fermentation of sorghum. The decrease in the fat composition during fermentation observed in this study could be attributed to the fact that biochemical and physiological changes that occurred during fermentation require energy and part of the lipids contained in the samples were utilized for this purpose [32, 33]. It could also be due to the production of aroma compounds through the breakdown of fatty acids and glycerol by the fermenting organisms [24]. Reports indicate that high fat content triggers rancidity during storage, giving rise to off flavor [30,34]. Therefore, fermentation with lactic acid bacteria consortium could serve as an effective way of reducing the fat composition of samples. Moreover, the present report has shown that LAB consortium fermentation is more effective in fat content reduction.

The protein content in this study increased from $10.39 \pm 0.27 \%$ in the unfermented sample to $13.94 \pm 0.87 \%$ in LAB consortium from sorghum-fermented sample. This result is similar to the work of Afify et al. [5] who reported $11.65-12.46 \%$ protein in raw sorghum samples. The result also agreed with the report of Johnson et al. [35] that crude protein in whole sorghum grain ranged from 10.30 to 14.90 . Chung et al. [36] reported that protein content of sorghum varies from 11.23 to 13.42 . The increase in protein content with fermentation is consistent with the work of Adegbehingbe [27] and fall within the range of 9.1-12.7\% reported by Yagoub et al. [29]. Abdelseed et al. [37] also reported increase in protein content of sorghum after fermentation. This increase could be attributed to the activities and increase in the number of fermenting microorganisms $[38,39]$. It can also be due to proteolytic enzymes produced by the fermenting organisms $[25,40]$ or the organisms may have produced proteins from the substrates leading to increased amino acids [41]. The highest increase in the protein content was observed in 48-h LAB consortium from sorghum-fermented samples, followed by 48-h LAB-consortium from maize-fermented sample and then 48-h naturally fermented sample. The present report has demonstrated the more effectiveness of the $\mathrm{LAB}$ consortium from sorghum and $\mathrm{LAB}$ consortium from maize in improving the palatability and texture of the final product [30].

The fiber content of sorghum flour in this study decreased from $1.96 \pm 0.05$ to $0.54 \pm 0.04 \%$. The decrease differed significantly $(p<0.05)$ when LAB consortium from sorghum-fermented sample is compared to $\mathrm{LAB}$ consortium from maize-fermented and naturally fermented samples. This observation is consistent with the report of Adegbehingbe [27] and compared favourably with the work of Alemu [42] and Ojokoh and Bello [24]. The general decrease in the fiber content could be due to the ability of the fermenting organisms to break down some components of the fiber or can be due to the enzymatic breakdown of the fiber during fermentation by lactic acid [24]. The highest decrease in fiber content was observed in LAB consortium from sorghum-fermented sample, followed by LAB consortium from maize-fermented sample, and then naturally fermented sample. The present investigation has also shown the effectiveness of the LAB consortia from maize and sorghum in metabolizing the fiber more than natural fermentation.

The carbohydrate composition in this study decreased with increasing fermentation time. The variations do not differ significantly $(p>0.05)$ when compared between LAB consortium from sorghum-fermented, LAB consortium from maize-fermented and naturally fermented sample. The result in this study falls within the range $70-80 \%$ reported by Yagoub et al. [29] and also agreed with the work that reported reduction in carbohydrate after fermentation [24]. This could be due to the fact that lactic acid bacteria utilize some of the sugars for growth 
and other metabolic activities. The decrease in carbohydrate content could be due to hydrolyses of starch by amylases produced by LAB. Moreover, Roger et al. [43] indicated that $\mathrm{LAB}$ from maize has strong amylolytic activity.

The in vitro starch digestibility (IVSD) of the samples in the present study was lowest in the natural fermentation. This could be attributed to the restriction of starch caused by the endosperm protein as reported by Singh et al. [6]. Fermentation resulted in significant increase $(p<0.05)$ in the IVSD of the flour. This is in agreement with a previous report for sorghum, maize and millet with increasing fermentation time [6] which could be attributed to the role of fermentation in making starch more accessible to the digestive enzymes $[6,44]$.

In the present study, fermentation was found to cause significant increase $(p<0.05)$ in the in vitro protein digestibility of the flour. The changes in LAB consortium from maize-fermented and $\mathrm{LAB}$ consortium from sorghum-fermented samples do not differ significantly. The starter organisms may have produced proteolytic enzymes which could be responsible for the increased protein digestibility [6]. This result also agrees with other reports on maize cultivars [45] which were attributed to the partial degradation of storage proteins into simple and more soluble products. Also, the reduction in $\mathrm{pH}$ during fermentation which plays an important role in enhancing the proteolytic enzyme activity may have contributed, and in turn leads, to the breakdown of proteins into smaller polypeptides and amino acids which are easily digested [6]. The highest starch/protein digestibility was observed in samples fermented with the LAB consortia while the naturally fermented. This shows that $\mathrm{LAB}$ consortia fermentation is more effective in improving the IVSD and IVPD of the sample more than the naturally fermented and the unfermented sample.

In the present study, the total viable count and total lactic acid bacteria count increased consistently with fermentation. This is an indication that the organisms were able to grow utilizing the substrates. Coliform count was only observed at $0 \mathrm{~h}$ of the naturally fermented sample. Fungi were only observed at the naturally fermented samples. The low $\mathrm{pH}$ and increased population of $\mathrm{LAB}$ may have been the cause of the absence of coliform in the present study or production of antimicrobial substances other contaminating organisms [46].

The predominant organisms isolated from the present study belong to lactic acid bacteria (LAB) group and the yeast Saccharomyces cerevisiae. This showed the ability of the starter organisms to dominate the substrates. Similar organisms have been reported by Ojokoh and Bello [23] millet and soya-bean blend flours.

\section{Conclusion}

The proximate properties, in vitro protein and starch digestibility of maize and sorghum in the present study improved significantly $(p<0.05)$ after natural, LAB consortium from maize and $L A B$ consortium from sorghum fermentation. The highest improvement was observed in the samples fermented with the LAB consortia in all the parameters analyzed except moisture. The LAB consortium from maize-fermented and LAB consortium from sorghum-fermented samples did not differ significantly in most of the parameters analyzed. This suggests effectiveness of lactic acid bacteria consortium in improving the nutritional qualities as well as in vitro starch digestibility and in vitro protein digestibility of the sample more than the naturally fermented and the unfermented sample.

\section{Abbreviations}

LAB: lactic acid bacteria; IVSD: in vitro starch digestibility; IVPD: in vitro protein digestibility; PCA: plate count agar; MRS: de Mann Rogosa and Sharpe agar; MCA: MacConkey agar; SDA: Sabouraud Dextrose agar; TVC: total viable count; TLBC: total lactic acid bacteria count; TCC: total coliform count; TFC: total fungal count; FT: fermentation time; NF: natural fermentation; MF: LAB consortium from maize fermented; SF: LAB consortium from sorghum fermented.

\section{Authors' contributions}

$\mathrm{ACO}$ and RAO conceived and designed the experiments; $\mathrm{ACO}$ performed the experiments; $\mathrm{ACO}, \mathrm{OCU}$ and $\mathrm{HCO}$ analyzed the data; $\mathrm{ACO}$ wrote the paper. All authors edited the final manuscript. All authors read and approved the final manuscript.

\section{Author details \\ ${ }^{1}$ Department of Microbiology, Faculty of Pure and Applied Sciences, Federal University Wukari, P.M.B. 1020, Wukari, Taraba State, Nigeria. ${ }^{2}$ Department of Microbiology, Faculty of Biological and Physical Sciences, Abia State Univer- sity Uturu, P.M.B. 2000, Uturu, Abia State, Nigeria.}

\section{Acknowledgements}

The authors are grateful to the management of Federal Institute of Industrial Research Oshodi (FIIRO), Nigeria.

\section{Competing interests}

The authors declare that they have no competing interests.

\section{Availability of data and materials}

All relevant data generated during this study are within the paper and its additional information files.

\section{Consent for publication}

Not applicable.

Ethics approval and consent to participate Not applicable.

Funding

None.

\section{Publisher's Note}

Springer Nature remains neutral with regard to jurisdictional claims in published maps and institutional affiliations.

Received: 24 October 2018 Accepted: 4 February 2019

Published online: 11 April 2019 


\section{References}

1. Adam IA, Abdalla AA, Khalid Al, El-Tinay AH. Effect of traditional processing on phosphorus content and some anti nutritional factors of pearl millet (Pennisetum glaucum L.). Res J Agric Biol Sci. 2010;6(3):176-80.

2. FAO. State of food insecurity in the world: monitoring progress towards the world food summit and millenium development goals. Rome: FAO; 2003

3. Mella ONO. Effects of malting and fermentation on the composition and functionality of sorghum flour. Dissertations, Theses, \& Student Research in Food Science and Technology. 12. 2011. http://digitalcommons.unl. edu/foodscidiss/12. Accessed 23 Feb 2016

4. Shehab GG, Kansowa OA, El-Beltagi HS. Effects of various chemical agents for alleviation of drought stress in rice plants (Oryza sativa L.). Not Bot Horti Agrobo. 2010;38(1):139-48.

5. Afify AMR, El-Beltagi HS, Abd El-Salam SM, Omran AA. Effect of soaking, cooking, germination and fermentation processing on proximate analysis and mineral content of three white sorghum varieties (Sorghum bicolor $\mathrm{L}$. Moench). Not Bot Horti Agrobo. 2012;40(2):92-8.

6. Singh A, Yadav N, Sharma S. Effect of fermentation on physicochemical properties \& in vitro starch and protein digestibility of selected cereals. Int J Agric Food Sci. 2012;2(3):66-70.

7. Masood MI, Qadir MI, Shirazi JH, Khan IU. Beneficial effects of lactic acid bacteria on human beings. Crit Rev Microbiol. 2012;37(1):91-8.

8. Kohajdová Z, Karovičová J. Fermentation of cereals for specific purpose. J Food Nutr Res. 2007:46:51-7.

9. Ramos CL, Thorsen L, Schwan RF, Jespersen L. Strain-specific probiotics properties of Lactobacillus fermentum, Lactobacillus plantarum and Lactobacillus brevis isolates from Brazilian food products. Food Microbiol. 2013;36:22-9.

10. Owusu-Kwarteng J, Tano-Debrah K, Akabanda F, Jespersen L. Technological properties and probiotic potential of Lactobacillus fermentum strains isolated from West African fermented millet dough. BMC Microbiol. 2015;15:261.

11. Ogodo AC, Ugbogu OC, Onyeagba RA, Orji FA. Dynamics of functional properties of sorghum fermented with lactic acid bacteria consortium isolated from cereals. Int Food Res J. 2017:24(6):666-2671.

12. Ogodo AC, Ugbogu OC, Onyeagba RA, Okereke HC, Agwaranze DI. Dynamics of functional properties of maize flours fermented with lactic acid bacteria (LAB)-consortium isolated from cereals. FUW Trends Sci Technol. 2016:1:134-8.

13. AOAC. Official methods of analysis. 18th ed. Gaithersburg: Association of Official Analytical Chemists; 2005. p. 1-34.

14. Monjula S, John E. Biochemical changes and in vitro protein digestibility of endosperm of germinating Dolichos lablab. J Sci Food Agric. 1991;55:429-38

15. Ogodo AC, Ugbogu OC, Ekeleme UG. Bacteriological quality of commercially prepared fermented Ogi (Akamu) sold in some parts of South Eastern Nigeria. Int J Biol Biomol Agri Food Biotechnol Eng. 2015;9:677-80.

16. Fawole MO, Oso BA. Laboratory manual of microbiology. Ibadan: Spectrum Books Limited; 1988

17. Holt JG, Krieg NR, Sneath PH, Staley JT, Williams ST. Bergey's manual of determinative bacteriology. 9th ed. Baltimore: Williams and Wilkins; 1994. p. 650-851.

18. Okereke HC, Kanu IJ. Identification and characterization of microorganisms, pp. 95-110. In: Onyeagba A, editor. Laboratory guide for microbiology. Okigwe: Crystal Publishers; 2004. p. 22-220.

19. Ogodo AC, Ugbogu OC, Onyeagba RA, Okereke HC. In-vitro starch and protein digestibility and proximate composition of soybean flour fermented with lactic acid bacteria (LAB) consortia. Agric Nat Res. 2018. https://doi.org/10.1016/j.anres.2018.10.001.

20. Barnett JA, Payne RW, Yarrow D. Yeasts characteristics and identification. 3rd ed. Cambridge: Cambridge University Press; 2000.

21. De-Hoog GS, Guarro J, Gené J, Figueras MJ. Atlas of clinical fungi. 2nd ed. Reus: Centraalbureau voor Schimmelcultures, Utrecht/Universitat Rovira i Virgili; 2000

22. Navis SS, Bandyopadhyay R, Hall AJ, Bramel-Cox PJ. A pictorial guide for the identification of mold fungi on sorghum grain. Information Bulletin no. 59. Hyderbad: International Crops Research Institute for the Semi-Arid Tropics; 1999. p. 118
23. Ogunsakin OA, Banwo K, Ogunremi OR, Sanni Al. Microbiological and physicochemical properties of sourdough bread from sorghum flour. Int Food Res J. 2015:22(6):2610-8.

24. Ojokoh A, Bello B. Effect of fermentation on nutrient and anti-nutrient composition of millet (Pennisetum glaucum) and soyabean (Glycine max) blend flours. J Life Sci. 2014;8(8):668-75.

25. Ojokoh AO, Fayemi OE, Ocloo FCK, Nwokolo Fl. Effect of fermentation on proximate composition, physicochemical and microbial characteristics of pearl millet (Pennisetum glaucum (L.) R. Br.) and Acha (Digitaria exilis (Kippist) Stapf) flour blends. J Agric Biotechnol Sust Dev. 2015;7(1):1-8.

26. Batool SA, Rauf N, Tahir SS, Kalsoom R. Microbial and physico-chemical contamination in the wheat flour of the twin cities of Pakistan. Int J Food Saf. 2012;14:75-82.

27. Adegbehingbe KT. Microbiological analyses and nutrient composition of sorghum co-fermented with Lima bean seeds. Cur Res Microbiol Biotechnol. 2014:2(4):431-7.

28. Yusufu PA, Egbunu FA, Egwujeh SID, Opega GL, Adikwu MO. Evaluation of complementary food prepared from sorghum, African Yam Bean (Sphenostylis stenocarpa) and Mango Mesocarp Flour Blends. Pak J Nutr 2013;12(2):205-8

29. Yagoub AE, Suleiman AME, Gadir WSA. Effect of fermentation on the nutritional and microbiological quality of dough of different sorghum varieties. J Sci Technol. 2009;10(3):109-18.

30. Ntuli V, Mekibib SB, Molebatsi N, Makotoko M, Chatanga P, Asita OA Microbial and physicochemical characterization of maize and wheat flour from a milling company, Lesotho. Int J Food Saf. 2013;15:11-9.

31. El Maki HB, Abdel Rahaman SM, Idris WH, Hassan AB, Babiker EE, El Tinay $\mathrm{AH}$. Content of antinutritional factors and $\mathrm{HCl}$-extractability of minerals from white bean (Phaseolus vulgaris) cultivars: influence of soaking and or cooking. Food Chem. 2007;100:362-8.

32. El-Beltagi HS, Mohamed AA, Mekki BB. Differences in some constituents, enzymes activity and electrophoretic characterization of different rapeseed (Brassica napus L.) cultivars. Ann Univ Oradea Fascicle Biol Tom. 2011;18(1):39-46.

33. Afify AMR, Rashed MM, Ebtesam AM, El-Beltagi HS. Effect of gamma radiation on protein profile, protein fraction and solubility of three oil seeds. Not Bot Horti Agrobo. 2011;39(2):90-8.

34. Shobha D, Prasanna KMK, Puttaramanaik STA. Effect of antioxidant on the shelf life of quality protein maize flour. Indian J Fund Appl Life Sci. 2011;1:129-40.

35. Johnson WB, Ratnayake WS, Jackson DS, Lee K, Herrman TJ, Bean SR, Mason SC. Factors affecting the alkaline cooking performance of selected corn and sorghum hybrids. Cereal Chem. 2010;87(6):524-31.

36. Chung M, Kim E, Yeo M, Kim S, Seo M, Moon H. Antidiabetic effects of three Korean sorghum phenolic extracts in normal and streptozotocininduced diabetic rats. Food Res Int. 2011;44:127-32.

37. Abdelseed BH, Abdalla AH, El-Gasim A, Yagoub A, Mohamed Ahmed IA, Babiker EE. Some nutritional attributes of selected newly developed lines of sorghum (Sorghum bicolor) after fermentation. J Agric Sci Technol. 2011;13:399-409.

38. Ojokoh AO, Daramola MK Oluoti OJ. Effect of fermentation on nutrient and anti-nutrient composition of breadfruit (Treculia africana) and cowpea (Vigna unguiculata) blend flours. Afr J Agric Res. 2013:8:3566-70.

39. Ojokoh AO, Fayemi EO, Ocloo FCK, Alakija O. Proximate composition, antinutritional contents and physicochemical properties of breadfruit (Treculia africana) and cowpea (Vigna unguiculata) flour blends fermented with Lactobacillus plantarum. Afr J Microbiol Res. 2014;8:1352-9.

40. Amankwah E, Barimah J, Acheampong R, Addai L, Nnaji C. Effect of fermentation and malting on the viscosity of maize-soyabean weaning blends. Pak J Nutr. 2009:8:1671-5.

41. Babalola RO, Giwa OE. Effect of fermentation on nutritional and anti-nutritional properties of fermenting Soy beans and the antagonistic effect of the fermenting organism on selected pathogens. Int Res J Microbiol. 2012:3(10):333-8.

42. Alemu MK. The effect of natural fermentation on some antinutritional factors, minerals, proximate composition and sensory characteristics in sorghum based weaning food. M.Sc. Thesis, Addis Ababa, University, Ethiopia. 2009. 56-83.

43. Roger T, Léopold TN, Funtong MM. Nutritional properties and antinutritional factors of corn paste (Kutukutu) fermented by 
different strains of lactic acid bacteria. Int J Food Sci. 2015. https://doi. org/10.1155/2015/502910.

44. Hassan IAG, El Tinay AH. Effects of fermentation on tannin content and in vitro protein and starch digestibility of two sorghum cultivars. Food Chem. 1995;53:149-51.

45. Mohiedeen IE, Tinay AHE, Elkhalya AEO, Babiker EE, Mallasiy LO. Effect of fermentation on in vitro protein digestibility, protein fractions and amino acids composition of maize (Zea mays Linnaus) cultivars. Elec J Environ Agric Food Chem. 2010;9:838-47.

46. Olanipekun B, Adelekun O. Nutritional and microbial attributes of soybean (Glycine max) during fermentation with Rhizopus oligosporus. Food Sci Qual Manag. 2015;39:111-8. 